\title{
Ursolic Acid Induces Apoptotic Cell Death Through AIF and Endo G Release Through a Mitochondria-dependent Pathway in NCI-H292 Human Lung Cancer Cells In Vitro
}

\author{
CHIUNG-JU CHEN ${ }^{1,2}$, YUNG-LUEN SHIH ${ }^{2,3,4}$, MING-YANG YEH ${ }^{5}$, NIEN-CHIEH LIAO ${ }^{6}$, \\ HSUEH-YU CHUNG ${ }^{1}$, KO-LIN LIU ${ }^{2}$, MEI-HUI LEE ${ }^{7}$, PEI-YI CHOU ${ }^{6}$, \\ HSIN-YU HOU ${ }^{6}$, JIANN-SHANG CHOU ${ }^{8 *}$ and JING-GUNG CHUNG ${ }^{9}, 10^{*}$ \\ ${ }^{1}$ Jen-Teh Junior College of Medicine, Nursing and Management, Miaoli, Taiwan, R.O.C.; \\ ${ }^{2}$ Department of Pathology and Laboratory Medicine, Shin Kong Wu Ho-Su Memorial Hospital, Taipei, Taiwan, R.O.C., \\ ${ }^{3}$ School of Medical Laboratory Science and Biotechnology, Taipei Medical University, Taipei, Taiwan, R.O.C.; \\ ${ }^{4}$ School of Medicine, College of Medicine, Fu-Jen Catholic University, New Taipei, Taiwan, R.O.C.; \\ Departments of ${ }^{5}$ Education and Research, ${ }^{6}$ Clinical Pathology and ${ }^{8}$ Pathology, \\ Cheng-Hsin General Hospital, Taipei, Taiwan, R.O.C.; \\ ${ }^{7}$ Department of Genetic Counseling Center, Changhua Christian Hospital, Changhua, Taiwan, R.O.C.; \\ ${ }^{9}$ Department of Biological Science and Technology, China Medical University, Taichung, Taiwan, R.O.C.; \\ ${ }^{10}$ Department of Biotechnology, Asia University, Taichung, Taiwan, R.O.C.
}

\begin{abstract}
Background/Aim: Ursolic acid (UA), a triterpene compound present in natural plants, has been shown to induce cytotoxic effects on many human cancer cells through induction of cell-cycle arrest and apoptosis. This study investigated the effects of UA on human lung cancer NCI-H292 cells in vitro. Materials and Methods: Flow cytometric assay was used to measure the percentage of cell viability, apoptotic cell death by double staining of annexin $V$ and propidium iodide (PI), production of reactive oxygen species (ROS) and $\mathrm{Ca}^{2+}$, and mitochondriaI membrane potential $\left(\Psi_{m}\right)$. UA-induced chromatin condensation and DNA fragmentation were examined by 4',6-diamidino-2-phenylindole staining and DNA gel electrophoresis, respectively. Western blotting was used to
\end{abstract}

This article is freely accessible online.

\footnotetext{
*These Authors contributed equally to this study.

Correspondence to: Jing-Gung Chung, Ph.D., Department of Biological Science and Technology, China Medical University. No 91, Hsueh-Shih Road, Taichung, Taiwan, ROC. Tel: +886 422053366 ext. 8000, Fax: +886 422053764, e-mail: jgchung@mail.cmu.edu.tw and Jiann-Shang Chou, Department of Pathology, Cheng-Hsin General Hospital, No.45, Cheng Hsin St., Pai-Tou, Taipei, Taiwan, R.O.C. Tel: +886228264400 ext. 5850, Fax: +886 228264517, e-mail: ch1835@chgh.org.tw
}

Key Words: Ursolic acid (UA), DNA fragmentation, apoptosis, NCIH292 human lung cancer cells. examine the changes of apoptosis-associated protein expression in NCI-H292 cells. Results: UA reduced cell viability and induced apoptotic cell death. UA increased $\mathrm{Ca}^{2+}$ production, reduced $\Psi_{m}$, but did not affect ROS production in NCI-H292 cells. UA increased apoptosis-inducing factor (AIF) and endonuclease G in NCI-H292 cells. Conclusion: Based on these observations, we suggest UA induces apoptotic cell death via AIF and Endo G release through a mitochondria-dependent pathway in NCI-H292 cells.

Lung cancer is the leading cause of cancer-associated death worldwide (1) and divided into non-small-cell lung cancer (NSCLC) and small-cell lung cancer (SCLC). The most common type is NSCLC accounting for about $80-85 \%(2,3)$, with poor prognosis and a high incidence of recurrence (4). NSCLC includes adenocarcinoma, squamous cell carcinoma, and large-cell carcinomas (5). Although advanced diagnostics and therapeutics have been developed, the treatment and outcome of lung cancer is still unsatisfactory $(4,6-8)$.

Characteristics of cancer include uncontrolled cell-cycle progression and deregulation of apoptosis. One of the therapeutic strategies for chemotherapy is to induce cancer cell apoptosis. Apoptosis plays a critical role in the balance between cellular replication and death, in particular for elimination of unwanted, damaged or infected cells $(9,10)$. Much evidence has shown that chemotherapy drugs in clinical used for patients with cancer via the activation of apoptotic pathways in cancer cells (11-13). When the mitochondria membrane potential $\left(\Psi_{m}\right)$ decreases, cytochrome $c$ binds to 
apoptotic peptidase activating factor 1 (APAF1) and caspase9 to result in a complex which activates caspase-3, leading to cell apoptosis (14), or induces the release of transcription factor from mitochondria for nucleus translocation to develop apoptosis $(15,16)$.

Natural compounds from plants have been used as anticancer drugs for various cancer types in the clinic (17) such as taxol and vincristine which have been widely used to treat breast, ovary and lung cancer. Ursolic acid (UA), a triterpene compound present in plants (18), such as berries, apples, rosemary and some medicinal plants such as Rosmarinus officinalis, Oldenlandia diffusa, Eriobotrya japonica, and Glechoma hederaceae (19), has antitumor activity in many human cancer cell lines (breast, lung, pancreatic, and prostate cancer) $(20,21)$. Literature shows that one of the important functions of UA in antitumor activity is to induce cancer cell apoptosis (22-24) and cellcycle arrest $(25,26)$. UA derivatives were also shown to be potential therapy candidates in studies on NSCLC cell lines (H460, H322, H460 LKB1t/t) (27).

Although numerous studies have shown that UA induced cell apoptosis and cell-cycle arrest in many human cancer cell lines including NSCLC cell lines, however, none included NSCLC NCI-H292 cells. Therefore, we investigated the effects of UA on the NCI-H292 human lung cancer cells in vitro.

\section{Materials and Methods}

Chemicals and reagents. UA, dimethyl sulfoxide (DMSO, as a carrier solvent), propidium iodide (PI), 4',6-diamidino-2-phenylindole (DAPI), Tris-HCl, trypsin and Annexin V-FITC Apoptosis Detection Kit were obtained from Sigma Chemical Co. (St. Louis, MO, USA). Cell culture medium (RPMI-1640), fetal bovine serum (FBS) and penicillin-streptomycin were purchased from Invitrogen (Carlsbad, CA, USA). Primary antibodies against poly (ADP-ribose) polymerase 1 (PARP), caspase-7, cytochrome c, endonuclease G (EndoG), apoptosis-inducing factor (AIF), B-cell lymphoma 2 (BCL2), BCL2like 1 (BCL-Xs), BH3 interacting domain death agonist (BID), BH3only protein BID (tBID), and $\beta$-actin, and peroxidase-conjugated secondary antibodies were purchased from Cell Signaling Technology, Inc. (Beverly, MA, USA).

Cell culture. NCI-H292 human lung cancer cell line was obtained from the Food Industry Research and Development Institute (Hsinchu, Taiwan) and was maintained as described previously (28). Cells were grown in $10-\mathrm{cm}$ dishes in RPMI-1640 medium supplemented with $10 \%$ FBS, penicillin $(100 \mathrm{U} / \mathrm{ml})$ and streptomycin $(100 \mu \mathrm{g} / \mathrm{ml})$ in an atmosphere of $5 \% \mathrm{CO}_{2}$ at $37^{\circ} \mathrm{C}(28)$.

Cell viability assay. NCI-H292 cells were seeded at a density of $1 \times 10^{5}$ cells/well into 12 -well plates (Falcon, Franklin Lakes, NJ, USA) overnight before treatment. Cells were treated with UA at final concentration of $0,3,6,9,12$ and $15 \mu \mathrm{M}$ for 24 and $48 \mathrm{~h}$. Control cultures were treated with $0.1 \%$ DMSO. After incubation, the cells were washed with phosphate-buffered saline (PBS) and stained with PI $(5 \mu \mathrm{g} / \mathrm{ml})$ for measuring cell viability by flow cytometry (Becton-Dickinson, San Jose, CA, USA) as described previously (28).

Apoptotic cell death assay. The procedure was performed based on the guideline provided in Annexin V-FITC Apoptosis Detection Kit. NCI-H292 cells $\left(1 \times 10^{5}\right.$ cells/well $)$ were incubated with or without $12 \mu \mathrm{M}$ of UA for $0,6,12,24$ and $48 \mathrm{~h}$. All adhering and floating cells were harvested, washed twice with PBS and then transferred into sterile centrifuge tube and stained with annexin-V/PI for analysis of early and late apoptotic cell death by flow cytometry as described previously (28).

DAPI assay. NCI-H292 cells $\left(1 \times 10^{5}\right.$ cells/well $)$ in 12 -well plate were incubated with $0,3,6,9,12$ and $15 \mu \mathrm{M}$ of UA for 24 and 48 $\mathrm{h}$. At the end of incubation, cells were fixed in $3 \%$ paraformaldehyde in PBS for $20 \mathrm{~min}$ at room temperature then were washed with PBS and stained with DAPI solution $(2 \mu \mathrm{g} / \mathrm{ml})$. DNA condensation was examined and photographed under a fluorescence microscope as described previously (28). Head intensity was quantified using the CometScore ${ }^{\mathrm{TM}}$ Freeware analysis (TriTek Corporation, Sumerduck, VA, USA).

DNA fragmentation assay. The assay for DNA fragmentation was conducted according to the manufacturer's instructions using Suicide Track $^{\mathrm{TM}}$ DNA Ladder Isolation Kit (Calbiochem, CA, USA). NCI$\mathrm{H} 292$ cells $\left(5 \times 10^{5}\right.$ cells/dish $)$ in a $10-\mathrm{cm}$ dish were incubated with 0 , $3,6,9$, and $12 \mu \mathrm{M}$ of UA for $48 \mathrm{~h}$. DNA was quantitated, analyzed using $1.5 \%$ agarose gel electrophoresis, and visualized and photographed under UV illumination as described previously (29).

Measurements of reactive oxygen species (ROS), intracellular $\mathrm{Ca}^{2+}$ and $\Psi_{m}$. Flow cytometric assay was used for measuring the production of ROS and $\mathrm{Ca}^{2+}$ and mitochondrial membrane potential $\left(\Psi_{m}\right)$. NCI-H292 cells $\left(1 \times 10^{5}\right.$ cells/well $)$ in 12 -well plate were treated with or without UA $(12 \mu \mathrm{M})$ for $0,1,3,6,9,12,24$ and 48 h. Cells were collected and re-suspended in $500 \mu \mathrm{l}$ of 2',7'dichlorodihydrofluorescein diacetate $\left(\mathrm{DCFH}_{2}\right.$-DA) $(10 \mu \mathrm{M}), 500 \mu \mathrm{l}$ of fluo-3-acetomethoxyester (Fluo-3/AM) $(2.5 \mu \mathrm{g} / \mathrm{ml})$, and $500 \mu \mathrm{l}$ of 3,3'-dihexyloxacarbo-cyanine iodide $\left(\mathrm{DiOC}_{6}\right)(4 \mu \mathrm{mol} / \mathrm{l})$ for 30 min and then to measure the changes of $\operatorname{ROS}\left(\mathrm{H}_{2} \mathrm{O}_{2}\right)$, intracellular $\mathrm{Ca}^{2+}$, and $\Psi_{m}$, respectively, by flow cytometry as described previously $(28,29)$. All samples were analyzed in triplicate.

Western blotting analysis. NCI-H292 cells were seeded in 10-cm dish at a density of $5 \times 10^{5}$ cells/dish and incubated with $12 \mu \mathrm{M}$ UA for 0 , $6,12,24$ and $48 \mathrm{~h}$. Cells were collected and measured total protein by the Bio-Rad protein assay kit (Bio-Rad, Hercules, CA, USA) with bovine serum albumin as the standard as described previously $(28,29)$. Proteins were electrophoresed by $10 \%$ sodium dodecyl sulfate polyacrylamide gels and transferred onto polyvinylidene fluoride membrane (BioRad, Hercules, CA, USA). The membranes were blocked in $5 \%$ nonfat dry milk in $50 \mathrm{mM}$ Tris (pH 7.6), $150 \mathrm{mM} \mathrm{NaCl}$ and $0.1 \%$ Tween 20 (TBST buffer) for $1 \mathrm{~h}$ at room temperature. After washing, the membrane was incubated with primary antibodies against PARP, caspase-7, cytochrome $c$, Endo G, AIF, BCL2, BCL-Xs, BID, and $\beta$-actin at $4^{\circ} \mathrm{C}$ overnight and washed with TBST. The membranes were incubated with horseradish peroxidase-conjugated anti-rabbit IgG. Immunoreactive proteins as secondary antibody and were visualized and detected by Immobilon ${ }^{\mathrm{TM}}$ Western Chemiluminescent 

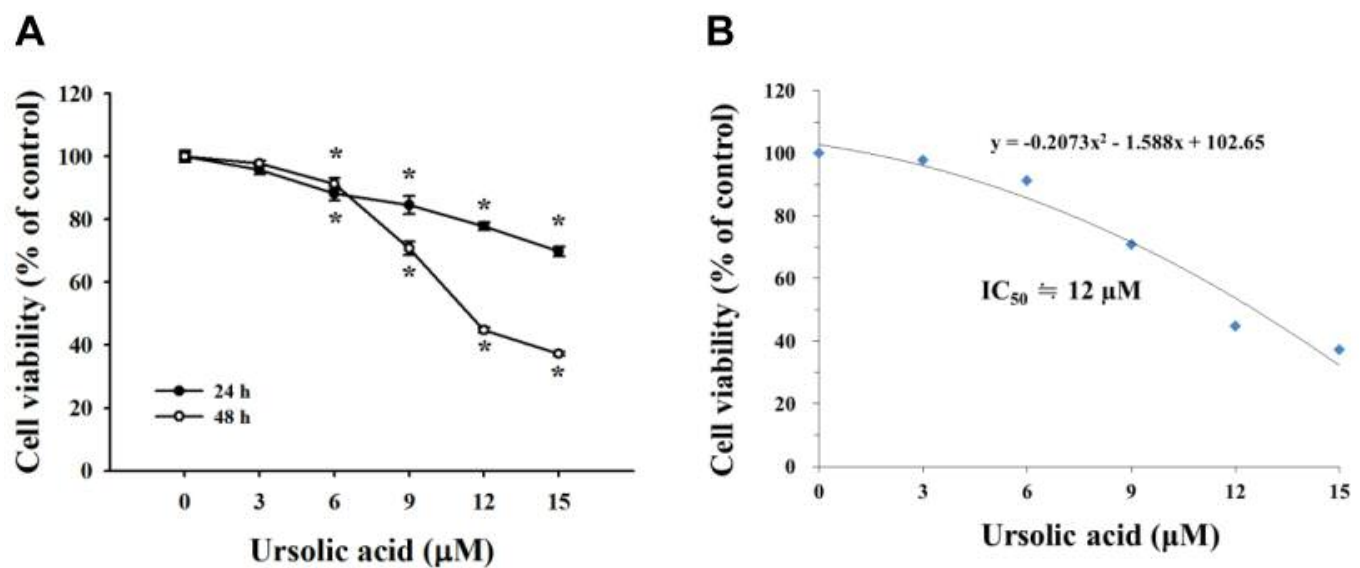

Figure 1. Effects of ursolic acid (UA) on cell viability of NCI-H292 cells. Cells ( $1 \times 10^{5}$ cells/well) were treated with UA (0, 3, 6, 9, 12 and $\left.15 \mu \mathrm{M}\right)$ for 24 and $48 \mathrm{~h}$. Cells were harvested for determining the percentage of viability as described in the Materials and Methods. IC $C_{50}$ : Concentration causing $50 \%$ cell death. *Significantly different from the control group at $p<0.05$ by one-way ANOVA.

A
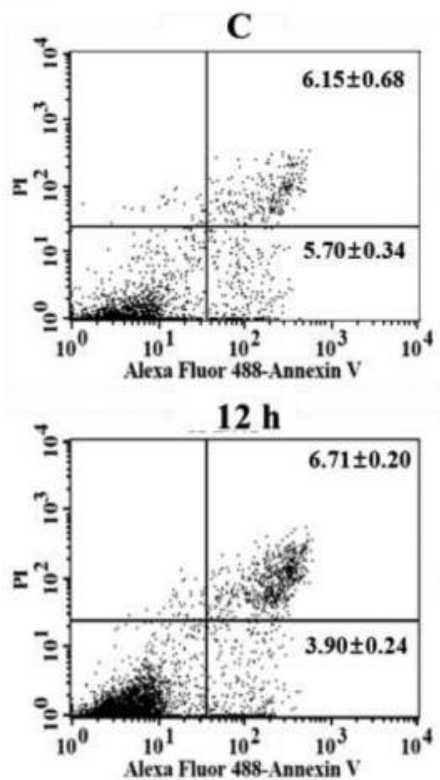

$48 \mathrm{~h}$

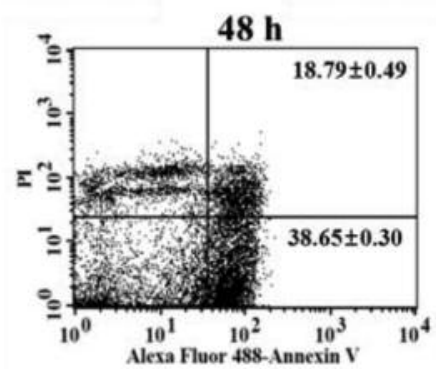

B

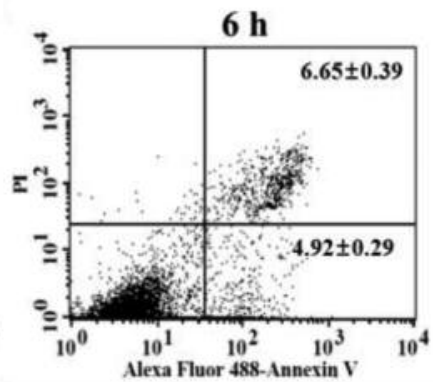

$24 \mathrm{~h}$

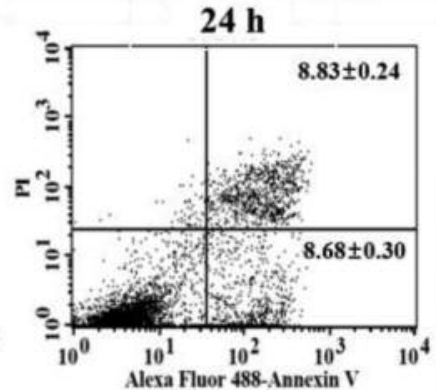

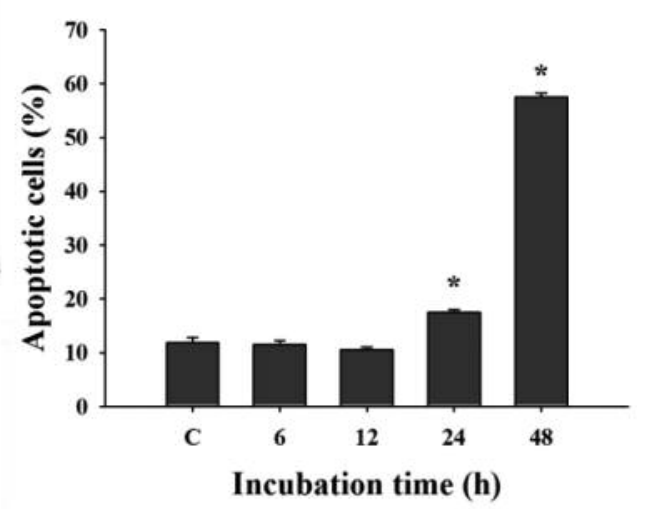

Incubation time (h)

Figure 2. Effects of ursolic acid (UA) on apoptotic cell death in NCI-H292 cells. Cells were treated with UA (12 $\mu$ M) for 0, 6, 12, 24 and 48 h and were measured for apoptotic cell death using annexin-V/propidium iodide (PI) double staining as described in the Materials and Methods. A: Representative profiles. B: Percentage of apoptotic cell death. *Significantly different from the control group (C) at p<0.05 by one-way ANOVA. 


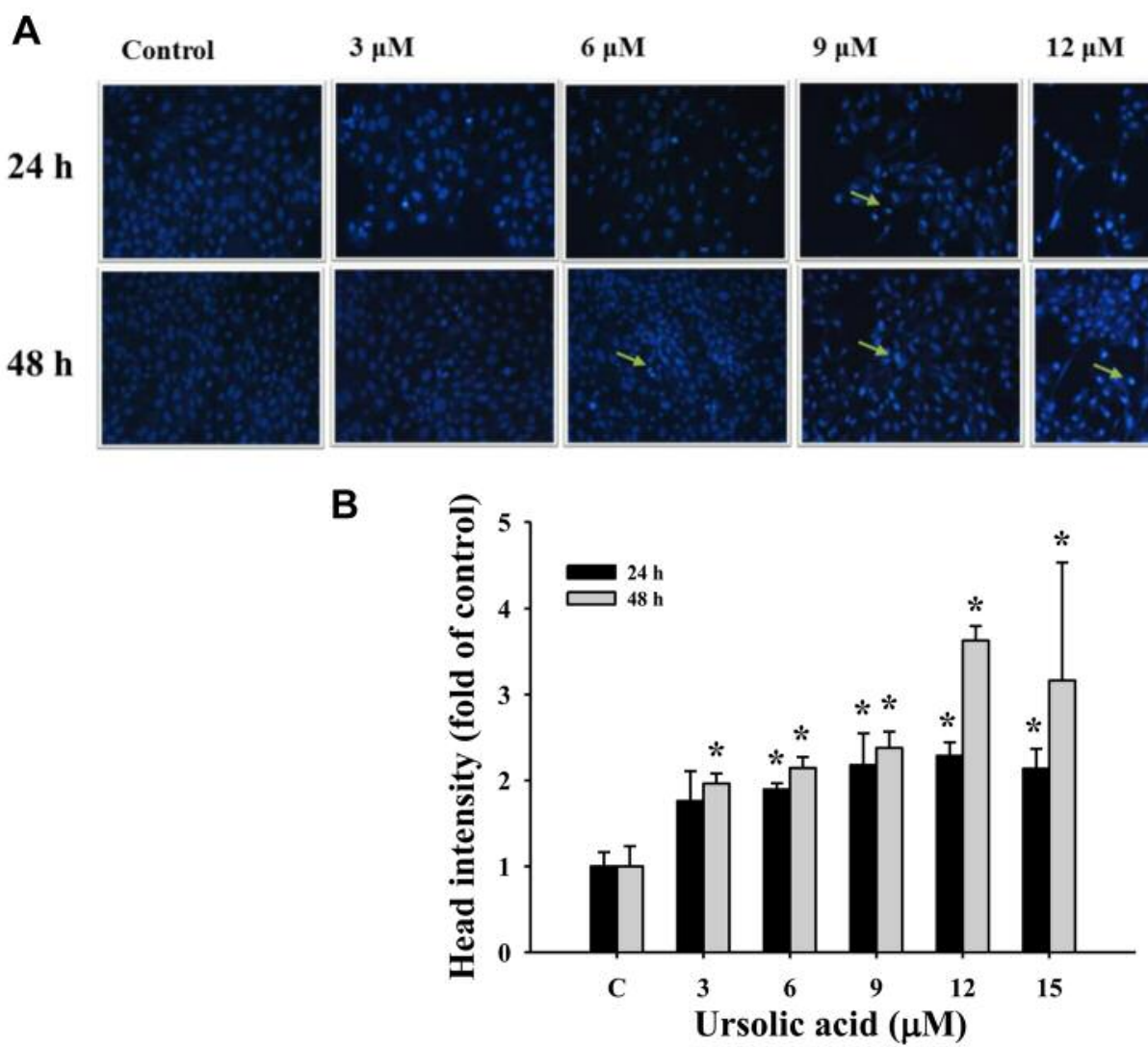

Figure 3. Effects of ursolic acid (UA) on chromosome structure in NCI-H292 cells. NCI-H292 cells were treated with UA (0, 3, 6, 9, 12 and 15 M) for 24 and $48 h$ and were stained with 4',6-diamidino-2-phenylindole dihydrochloride (DAPI), visualized using fluorescence microscopy and photographed as described in the Materials and Methods. Arrows indicate damaged cells. A: DAPI staining. B: Head intensity (fold of control). *Significantly different from the control group $(C)$ at $p<0.05$ by one-way ANOVA.

HRP Substrate (Millipore, Billerica, MA, USA) (28, 29). The band was quantification using imageJ software (version $1.49 \mathrm{o}$; National Institutes of Health, Bethesda, MD, USA).

Statistical analysis. Results are expressed as the mean \pm standard deviation from at least three experiments. Statistical differences between UA-treated and control groups were analyzed by one-way ANOVA analysis. Differences with $p<0.05$ were considered statistically significant.

\section{Results}

$U A$ reduced cell viability of NCI-H292 cells. The results indicated that $\mathrm{UA}$ at $6,9,12$ and $15 \mu \mathrm{M}$ significantly reduced viable NCI-H292 cells in dose-and time-dependent manners (Figure 1A). The half maximal inhibitory concentration $\left(\mathrm{IC}_{50}\right)$ of UA was $12 \mu \mathrm{M}$ (Figure $1 \mathrm{~B}$ ).

UA induced apoptotic cell death of NCI-H292 cells. The data indicated that $12 \mu \mathrm{M}$ of UA induced significant apoptotic cell death only after 24 and 48 h. UA-induced apoptotic cell

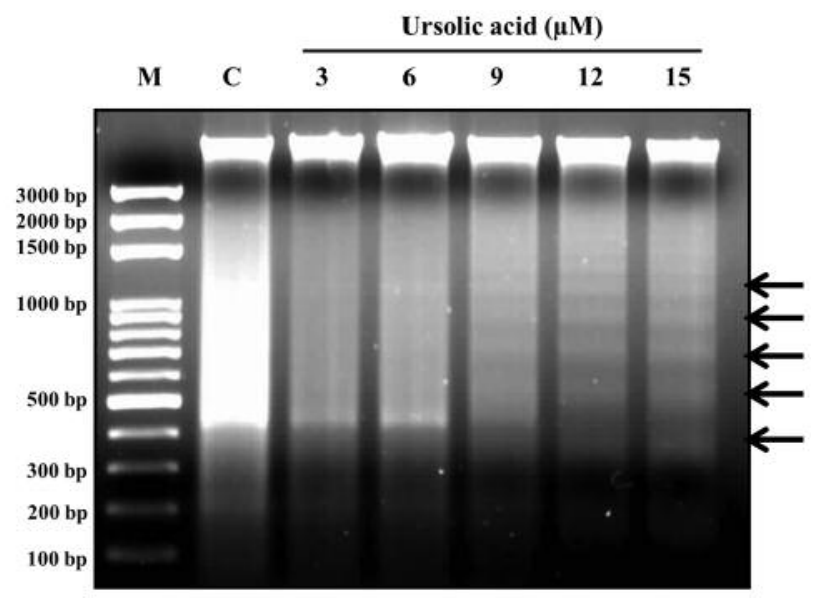

Figure 4. Effects of ursolic acid (UA) on DNA in NCI-H292 cells. NCIH292 cells $\left(5 \times 10^{5}\right.$ cells/dish $)$ in 10-cm dish were incubated with $0,3,6$, 9, 12 and $15 \mu M$. DNA was quantitated and was analyzed using $1.5 \%$ agarose gel electrophoresis, and visualized and photographed as described in the Materials and Methods. UA induced DNA fragmentation in NCI-H292 cells producing a ladder pattern. C: Control group. 
A
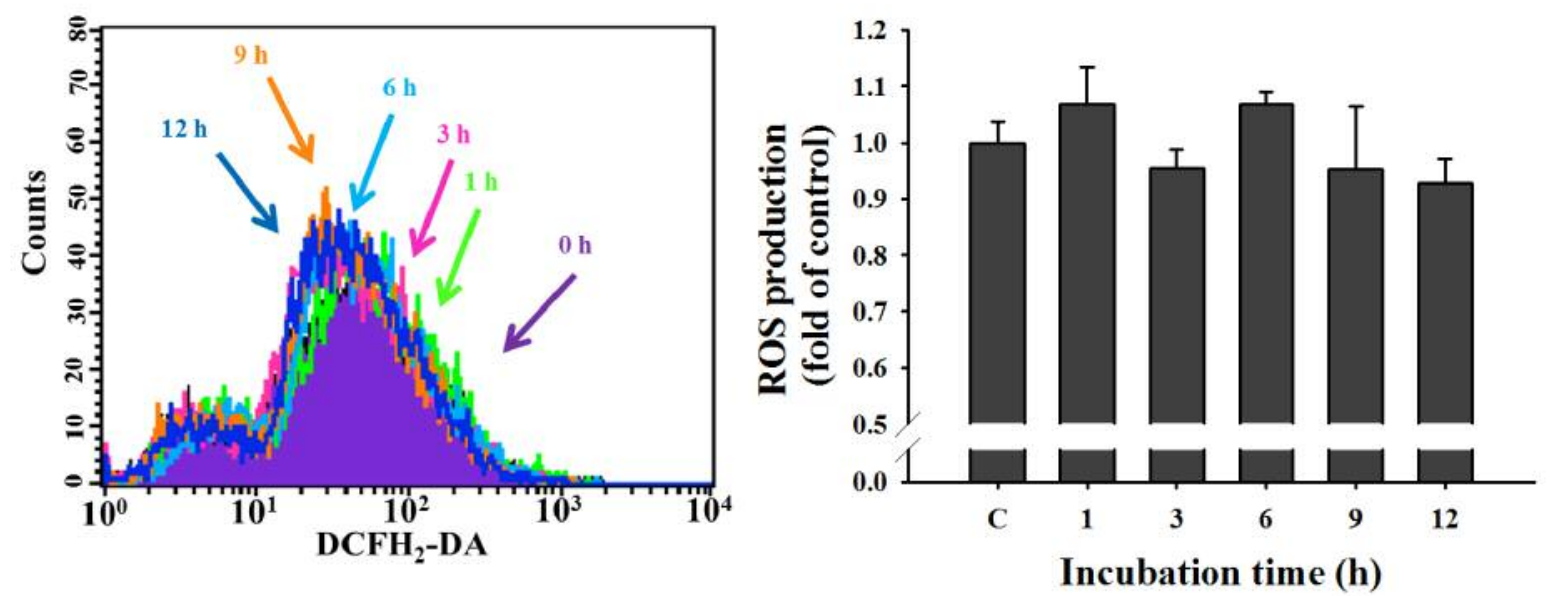

B
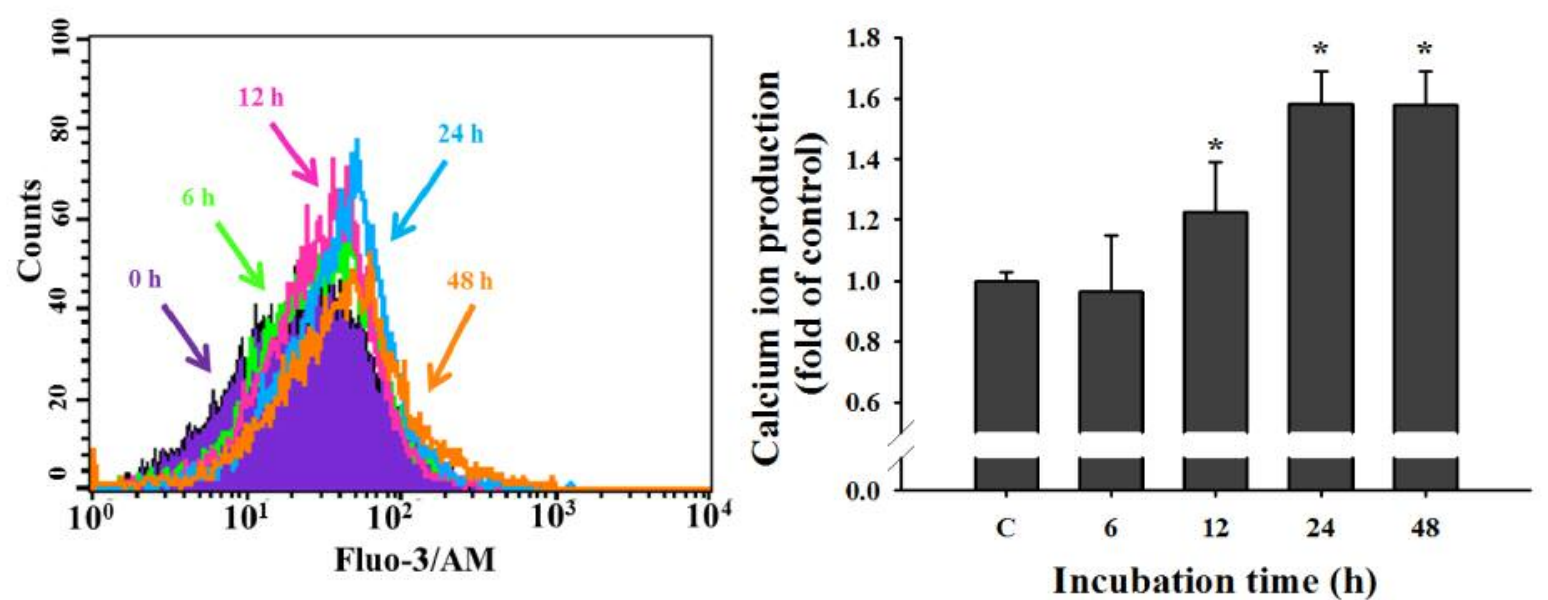

C
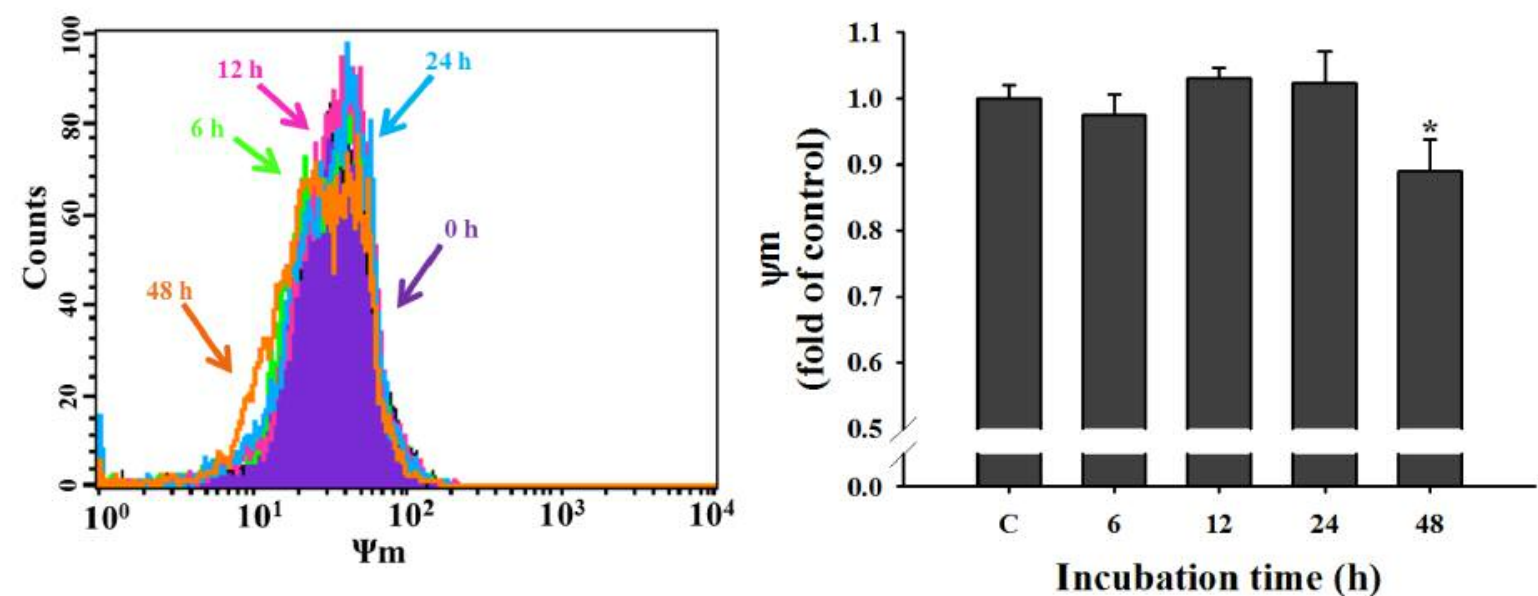

Figure 5. Effects of ursolic acid (UA) on reactive oxygen species (ROS), intracellular $\mathrm{Ca}^{2+}$ and mitochondrial membrane potential $\left(\Psi_{m}\right)$ in $\mathrm{NCI}$ H292 cells. NCI-H292 cells $\left(1 \times 10^{5}\right.$ cells/well $)$ were incubated with $U A(12 \mu M)$ for different time $(0,1,3,6,9$, and 12 h for reactive oxygen species assay and 0, 6, 12, 24 and $48 \mathrm{~h}$ for intracellular $\mathrm{Ca}^{2+}$ and mitochondrial membrane potential) and were measured for $\mathrm{ROS}(\mathrm{A}), \mathrm{Ca} \mathrm{a}^{2+}(B)$, and $\Delta \Psi_{m}(C)$ as described in the Materials and Methods. *Significantly different from the control group (C) at p<0.05 by one-way ANOVA. 
A

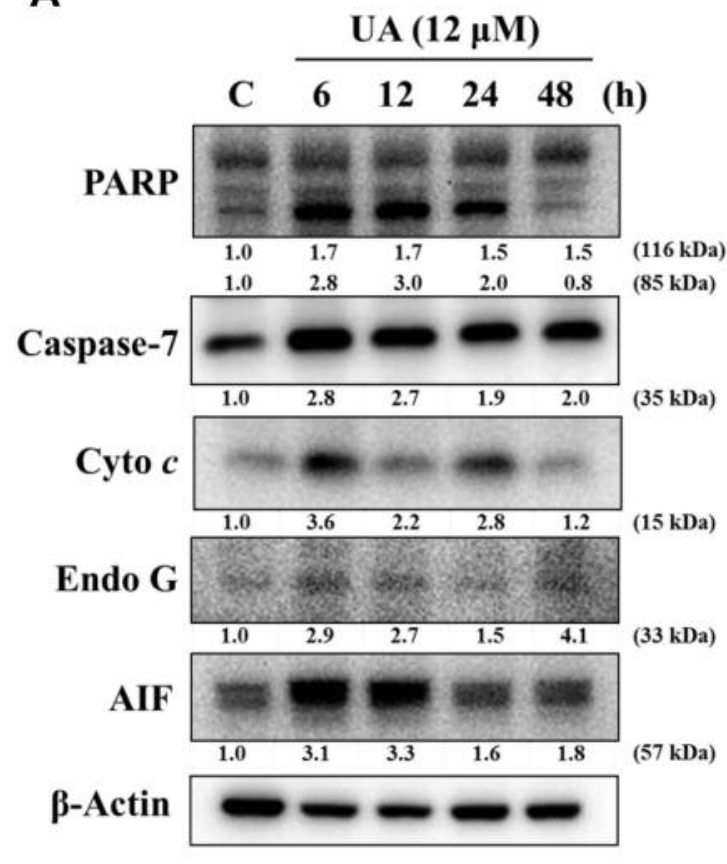

B

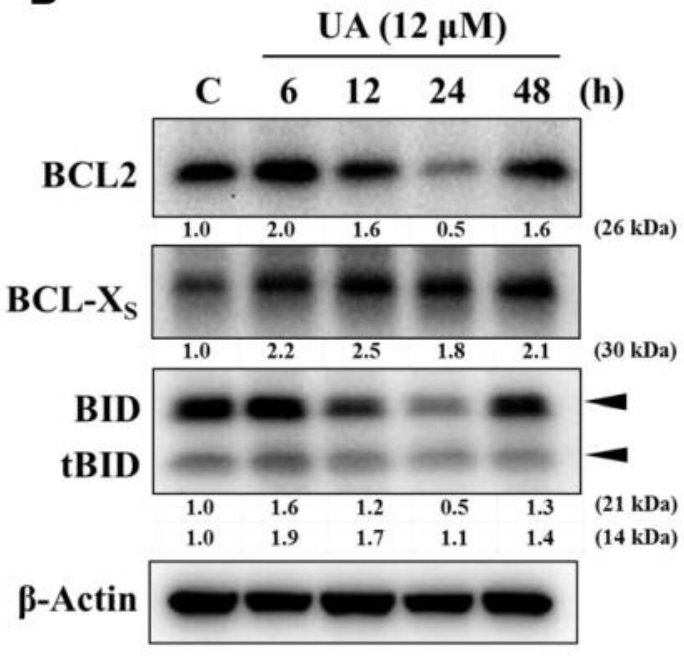

Figure 6. Ursolic acid (UA) altered expression of apoptosis-associated protein in NCI-H292 cells. Cells were treated with UA (12 $\mu$ M) for 0, 6, 12, 24 and $48 \mathrm{~h}$ and proteins were extracted and analyzed by western blotting as described in the Materials and Methods. A: Poly (ADP-ribose) polymerase 1 (PARP), caspase-7, cytochrome c (Cyto c), endonuclease $G$ (EndoG) and apoptosis-inducing factor (AIF); B: B-cell lymphoma 2 (BCL2), BCL2-like 1 (BCL-Xs), BH3 interacting domain death agonist (BID) and BH3-only protein BID (tBID).

death of NCI-H292 cells at $48 \mathrm{~h}$ treatment was higher than that at $24 \mathrm{~h}$ treatment (Figure 2).

UA induced chromatin condensation in NCI-H292 cells. UAtreated NCI-H292 cells were stained with DAPI, visualized and photographed using fluorescence microscopy. The fluorescence intensity of UA-treated NCI-H292 cells was brighter than that of controls in cells after 24 and $48 \mathrm{~h}$ treatment, respectively (Figure 3), indicating nicked DNA and chromatin condensation.

UA induced DNA fragmentation in NCI-H292 cells. DNA was isolated from UA-treated cells for DNA gel electrophoresis. As shown in Figure 4, results indicated that $\mathrm{UA}$ at 9,12 and $15 \mu \mathrm{M}$ clearly induced the DNA ladder (fragmentation), indicating UA induced apoptosis of NCIH292 cells in vitro.

$U A$ induced intracellular $\mathrm{Ca}^{2+}$ production and reduced the $\Psi_{m}$ in NCI-H292 cells. As shown in Figure 5A, 1-12 h treatment did not significantly increase ROS production in NCI-H292. UA increased $\mathrm{Ca}^{2+}$ release with 12,24 and $48 \mathrm{~h}$ treatment, time-dependently (Figure $5 \mathrm{~B}$ ). $\Psi_{\mathrm{m}}$ was reduced only at $48 \mathrm{~h}$ treatment in NCI-H292 cells (Figure 5C).
$U A$ altered expression of apoptosis-associated proteins in NCI-H292 cells. UA increased expression of PARP, caspase7, cytochrome c, Endo G and AIF (Figure 6A) and BCL-Xs, $\mathrm{BID}$ and tBID (Figure 6B) in NCI-H292 cells. UA reduced the expression of BCL2 and BID at $24 \mathrm{~h}$ treatment.

Based on these results, UA-induced apoptotic cell death may proceed via mitochondria-dependent pathways in NCIH292 cells.

\section{Discussion}

Numerous studies have shown that UA induced cytotoxic effects and reduced viable cells in many human cancer cell lines via induction of cell apoptosis (20-27) including human lung cancer cells (27), however, no report concerned NCI-H292 cells in vitro. Thus, in the present experiments, we investigated the effects of UA on NCIH292 human lung cancer cells in vitro. NCI-H292 cells were treated with different concentrations of UA for 24 and $48 \mathrm{~h}$ and results indicated that UA reduced total viable cell dose-dependently (Figure 1). This finding is in agreement with other reports showing that UA reduced total viable cells in other NSCLC cell lines (H460, H322, H460 LKB1t/t) (27). 
It is well documented that many chemotherapeutic drugs exert their antitumor functions via the induction of cell apoptosis in many human cancer cell types. Therefore, in order to further investigate whether UA reduced total viable cells through the induction of apoptotic cell death or not, annexin V/PI double staining was used for examining apoptotic cell death in NCI-H292 cells in vitro. Herein, the results indicated that UA at $12 \mu \mathrm{M}$ induced $18-58 \%$ of apoptotic cell deaths on 24 and $48 \mathrm{~h}$ treatment of NCI-H292 cells, respectively (Figure $2 \mathrm{~A}$ and $\mathrm{B}$ ). Annexin V/PI double staining is generally used to evaluate cell apoptosis. Apoptosis may develop as a defense mechanism after cells are damaged by noxious agents (10).

DAN damage including DNA condensation and DNA fragmentation is a characteristic of cell apoptosis. DNA damage was found using DAPI staining for examining DNA condensation and DNA gel electrophoresis for examining DNA fragmentation (DNA ladder) (cell apoptosis) (30); furthermore, internucleosomal fragmentation of nuclear DNA is a hallmark of apoptosis $(31,32)$. Staining of cells with DAPI did not lead to ultrastructural changes compared to those not stained with DAPI $(33,34)$. DAPI is a nucleicacid specific fluorophore that is widely used in chromosome staining (35). DAPI fluorescence can be used for investigating chromatin condensation in human chromosomes (34). Our results indicated that UA induced DNA condensation and fragmentation (ladder) and resulted in the induction of apoptotic cell death in NCI-H292 cells. Much evidence has shown that irradiation or drugs used for cancer chemotherapy lead to DNA damage followed by apoptotic death through a $p 53$-dependent pathway $(36,37)$.

Herein, results indicated that UA increased the levels of $\mathrm{Ca}^{2+}$ with $12-48 \mathrm{~h}$ treatment, and reduced $\Psi_{m}$ at $48 \mathrm{~h}$, however, it did not significantly affect the production of ROS by NCI-H292 cells. Literature reports that the production of ROS is involved in apoptotic cell death (38). However, we suggest that UA-induced cell apoptosis is independent of ROS pathways. $\mathrm{Ca}^{2+}$ uptake into the mitochondrial matrix was shown to be involved with cellular function (39). Our results indicated that UA-induced apoptotic cell death may involve a mitochondria-dependent pathway.

For further confirmation, western blotting assay was performed and showed that UA increased the expression of PARP, caspase 7, cytochrome $c$, AIF and Endo G in NCIH292 cells. The formation of FAS/FASL signaling complex which may trigger the activation of caspase- 8 for inducing cells apoptosis via the activation of caspase- $3,-6$, or -7 and then either directly (extrinsic pathway) or indirectly (intrinsic pathway) via the mitochondrial apoptotic signal pathway is well documented (40). BID, involved in the intrinsic signaling pathway, is cleaved by caspase- 8 to form the activated form tBID which is translocated to the mitochondria and disrupts organelles (41-43). Furthermore, the intrinsic signaling pathway involves dysfunction of mitochondria and leads to the release of cytochrome $c$ followed by activation of caspase-3, which results cell apoptosis (14) or directly releases apoptogenic molecules from mitochondria such as AIF and Endo G to induce apoptosis $(44,45)$. Other reports also showed that UA inhibited cell growth and induced apoptosis via the modulation of the phosphatidylinositol 3kinase/AKT/mammalian target of rapamycin pathway in human prostate cancer cells (46).

Based on these observations, the possible molecular mechanism of UA-induced apoptotic cell death may involve the release of apoptogenic molecules, in particular both AIF and Endo G, from mitochondria in NCI-H292 cells. Further studies should be performed to confirm these observations in vivo.

\section{Conflicts of Interest}

The Authors do not have any conflicts of interest to disclose in regard to this study.

\section{Acknowledgements}

This work was supported by grant 105-31 from Cheng-Hsin General hospital, Taipei Taiwan. Experiments and data analysis were performed in part through the use of the Medical Research Core Facilities Center, Office of Research \& Development at China Medical University, Taichung, Taiwan.

\section{References}

1 Ferlay J, Steliarova-Foucher E, Lortet-Tieulent J, Rosso S, Coebergh JW, Comber H, Forman D and Bray F: Cancer incidence and mortality patterns in Europe: Estimates for 40 countries in 2012. Eur J Cancer 49: 1374-1403, 2013.

2 Devesa SS, Bray F, Vizcaino AP and Parkin DM: International lung cancer trends by histologic type: Male:female differences diminishing and adenocarcinoma rates rising. Int J Cancer 117: 294-299, 2005.

3 Bunn PA Jr. and Lilenbaum R: Chemotherapy for elderly patients with advanced non-small-cell lung cancer. J Natl Cancer Inst 95: 341-343, 2003.

4 Siegel RL, Miller KD and Jemal A: Cancer statistics, 2015. CA Cancer J Clin 65: 5-29, 2015.

5 Wood SL, Pernemalm M, Crosbie PA and Whetton AD: Molecular histology of lung cancer: From targets to treatments. Cancer Treat Rev 41: 361-375, 2015.

6 Zheng F, Wu J, Zhao S, Luo Q, Tang Q, Yang L, Li L, Wu W and Hann SS: Baicalein increases the expression and reciprocal interplay of RUNX3 and FOXO3A through crosstalk of AMPKalpha and MEK/ERK1/2 signaling pathways in human nonsmall cell lung cancer cells. J Exp Clin Cancer Res 34: 41, 2015.

7 Reck M, Heigener DF, Mok T, Soria JC and Rabe KF: Management of non-small-cell lung cancer: Recent developments. Lancet 382: 709-719, 2013.

8 Rami-Porta R, Crowley JJ and Goldstraw P: The revised TNM staging system for lung cancer. Ann Thorac Cardiovasc Surg 15: 4-9, 2009. 
9 Fulda S, Galluzzi L and Kroemer G: Targeting mitochondria for cancer therapy. Nat Rev Drug Discov 9: 447-464, 2010.

10 Norbury CJ and Hickson ID: Cellular responses to DNA damage. Annu Rev Pharmacol Toxicol 41: 367-401, 2001.

11 Toshiya K TT, Akira H and Takuji T: Cancer chemoprevention through the induction of apoptosis by natural compounds. J Biophys Chem 3: 18, 2012.

12 Kemnitzer W, Sirisoma N, Nguyen B, Jiang S, Kasibhatla S, Crogan-Grundy C, Tseng B, Drewe J and Cai SX: Discovery of $\mathrm{N}$-aryl-9-oxo-9H-fluorene-1-carboxamides as a new series of apoptosis inducers using a cell-and caspase-based highthroughput screening assay. 1. Structure-activity relationships of the carboxamide group. Bioorg Med Chem Lett 19: 3045-3049, 2009.

13 Kemnitzer W, Kuemmerle J, Jiang S, Zhang HZ, Sirisoma N, Kasibhatla S, Crogan-Grundy C, Tseng B, Drewe J and Cai SX: Discovery of 1-benzoyl-3-cyanopyrrolo[1,2-a]quinolines as a new series of apoptosis inducers using a cell-and caspase-based high-throughput screening assay. Part 1: Structure-activity relationships of the 1- and 3- positions. Bioorg Med Chem Lett 18: 6259-6264, 2008.

14 Mandal M, Adam L and Kumar R: Redistribution of activated caspase-3 to the nucleus during butyric acid-induced apoptosis. Biochem Biophys Res Commun 260: 775-780, 1999.

15 Elmore S: Apoptosis: A review of programmed cell death. Toxicol Pathol 35: 495-516, 2007.

16 Wang $\mathrm{C}$ and Youle RJ: The role of mitochondria in apoptosis. Annu Rev Genet 43: 95-118, 2009.

17 Meral O, Alpay M, Kismali G, Kosova F, Cakir DU, Pekcan M, Yigit $\mathrm{S}$ and Sel T: Capsaicin inhibits cell proliferation by cytochrome $c$ release in gastric cancer cells. Tumour Biol 35: 6485-6492, 2014.

18 Ikeda Y, Murakami A and Ohigashi H: Ursolic acid: An anti-and pro-inflammatory triterpenoid. Mol Nutr Food Res 52: 26-42, 2008.

19 Taniguchi S, Imayoshi Y, Kobayashi E, Takamatsu Y, Ito H, Hatano T, Sakagami H, Tokuda H, Nishino H, Sugita D, Shimura $\mathrm{S}$ and Yoshida T: Production of bioactive triterpenes by Eriobotrya japonica calli. Phytochemistry 59: 315-323, 2002.

20 Salvador JA, Moreira VM, Goncalves BM, Leal AS and Jing Y: Ursane-type pentacyclic triterpenoids as useful platforms to discover anticancer drugs. Nat Prod Rep 29: 1463-1479, 2012.

21 Kashyap D, Tuli HS and Sharma AK: Ursolic acid (UA): A metabolite with promising therapeutic potential. Life Sci 146: 201-213, 2016.

22 Gao N, Cheng S, Budhraja A, Gao Z, Chen J, Liu EH, Huang C, Chen D, Yang Z, Liu Q, Li P, Shi X and Zhang Z: Ursolic acid induces apoptosis in human leukaemia cells and exhibits anti-leukaemic activity in nude mice through the PKB pathway. Br J Pharmacol 165: 1813-1826, 2012.

$23 \mathrm{Kim} \mathrm{KH}$, Seo HS, Choi HS, Choi I, Shin YC and Ko SG: Induction of apoptotic cell death by ursolic acid through mitochondrial death pathway and extrinsic death receptor pathway in MDA-MB-231 cells. Arch Pharm Res 34: 13631372, 2011.

24 Zhang Y, Kong C, Zeng Y, Wang L, Li Z, Wang H, Xu C and Sun Y: Ursolic acid induces PC-3 cell apoptosis via activation of JNK and inhibition of AKT pathways in vitro. Mol Carcinog 49: 374-385, 2010
25 Hsu YL, Kuo PL and Lin CC: Proliferative inhibition, cell-cycle dysregulation, and induction of apoptosis by ursolic acid in human non-small cell lung cancer A549 cells. Life Sci 75: 23032316, 2004

26 Weng H, Tan ZJ, Hu YP, Shu YJ, Bao RF, Jiang L, Wu XS, Li ML, Ding Q, Wang XA, Xiang SS, Li HF, Cao Y, Tao F and Liu YB: Ursolic acid induces cell cycle arrest and apoptosis of gallbladder carcinoma cells. Cancer Cell Int 14: 96, 2014.

27 Mendes VIS, Bartholomeusz GA, Ayres M, Gandhi V and Salvador JAR: Synthesis and cytotoxic activity of novel A-ring cleaved ursolic acid derivatives in human non-small cell lung cancer cells. Eur J Med Chem 123: 317-331, 2016.

28 Hsiao YT, Fan MJ, Huang AC, Lien JC, Lin JJ, Chen JC, Hsia TC, Wu RS and Chung JG: Deguelin impairs cell adhesion, migration and invasion of human lung cancer cells through the NF- $x$ B signaling pathways. Am J Chin Med 46: 209-229, 2018 .

29 Lin JJ, Wu CC, Hsu SC, Weng SW, Ma YS, Huang YP, Lin JG and Chung JG: Alpha-phellandrene-induced DNA damage and affect DNA repair protein expression in WEHI-3 murine leukemia cells in vitro. Environ Toxicol 30: 1322-1330, 2015.

30 Ohyama K, Enn P, Uchide N, Bessho T and Yamakawa T: Improvement of separation method of fragmented DNA from an apoptotic cell DNA sample for the quantitation using agarose gel electrophoresis. Biol Pharm Bull 24: 342-346, 2001.

31 Cohen JJ and Duke RC: Glucocorticoid activation of a calciumdependent endonuclease in thymocyte nuclei leads to cell death. J Immunol 132: 38-42, 1984.

32 Wyllie AH, Morris RG, Smith AL and Dunlop D: Chromatin cleavage in apoptosis: association with condensed chromatin morphology and dependence on macromolecular synthesis. J Pathol 142: 67-77, 1984.

33 Tarnowski BI, Spinale FG and Nicholson JH: DAPI as a useful stain for nuclear quantitation. Biotech Histochem 66: 297-302, 1991.

34 Estandarte AK, Botchway S, Lynch C, Yusuf M and Robinson I: The use of DAPI fluorescence lifetime imaging for investigating chromatin condensation in human chromosomes. Sci Rep 6: 31417, 2016.

35 Kapuscinski J: DAPI: A DNA-specific fluorescent probe. Biotech Histochem 70: 220-233, 1995.

36 Mirzayans R, Andrais B, Scott A and Murray D: New insights into p53 signaling and cancer cell response to DNA damage: Implications for cancer therapy. J Biomed Biotechnol 2012: 170325, 2012.

37 Parida PK, Mahata B, Santra A, Chakraborty S, Ghosh Z, Raha $\mathrm{S}$, Misra AK, Biswas $\mathrm{K}$ and Jana $\mathrm{K}$ : Inhibition of cancer progression by a novel trans-stilbene derivative through disruption of microtubule dynamics, driving $\mathrm{G}_{2} / \mathrm{M}$ arrest, and p53-dependent apoptosis. Cell Death Dis 9: 448, 2018.

38 Koul M, Kumar A, Deshidi R, Sharma V, Singh RD, Singh J, Sharma PR, Shah BA, Jaglan S and Singh S: Cladosporol A triggers apoptosis sensitivity by ROS-mediated autophagic flux in human breast cancer cells. BMC Cell Biol 18: 26, 2017.

39 Chou YC, Chang MY, Wang MJ, Harnod T, Hung CH, Lee HT, Shen CC and Chung JG: PEITC induces apoptosis of human brain glioblastoma GBM8401 cells through the extrinsic-and intrinsic-signaling pathways. Neurochem Int 81: 32-40, 2015. 
40 Lan YH, Chiang JH, Huang WW, Lu CC, Chung JG, Wu TS Jhan JH, Lin KL, Pai SJ, Chiu YJ, Tsuzuki M and Yang JS: Activations of both extrinsic and intrinsic pathways in HCT116 human colorectal cancer cells contribute to apoptosis through p53-mediated ATM/FAS signaling by Emilia sonchifolia extract, a folklore medicinal plant. Evid Based Complement Alternat Med 2012: 178178, 2012.

41 Pfeffer CM and Singh ATK: Apoptosis: A target for anticancer therapy. Int J Mol Sci 19, 2018. doi: 10.3390/ijms19020448. [Epub ahead of print]

42 Yenari MA and Han HS: Neuroprotective mechanisms of hypothermia in brain ischaemia. Nat Rev Neurosci 13: 267-278, 2012.

43 Li LY, Peng JD, Zhou W, Qiao H, Deng X, Li ZH, Li JD, Fu YD, Li S, Sun K, Liu HM and Zhao W: Potent hydrazone derivatives targeting esophageal cancer cells. Eur J Med Chem 148: 359-371, 2018.

44 Jantas D, Piotrowski M and Lason W: An involvement of PI3K/AKT activation and inhibition of AIF translocation in neuroprotective effects of undecylenic acid (UDA) against proapoptotic factors-induced cell death in human neuroblastoma SH-SY5Y cells. J Cell Biochem 116: 2882-2895, 2015.
45 Gupta S, Verma DK, Biswas J, Rama Raju KS, Joshi N, Wahajuddin and Singh S: The metabolic enhancer piracetam attenuates mitochondrion-specific endonuclease $\mathrm{G}$ translocation and oxidative DNA fragmentation. Free Radic Biol Med 73: 278-290, 2014.

46 Meng Y, Lin ZM, Ge N, Zhang DL, Huang J and Kong F: Ursolic acid induces apoptosis of prostate cancer cells via the PI3K/AKT/mTOR pathway. Am J Chin Med 43: 1471-1486, 2015.
Received November 19, 2018

Revised December 10, 2018

Accepted December 12, 2018 